212 Priscus, Fragmenta et Excerpta: Attila ve Bizans Tarihi. Çev. ve haz. Turhan Kaçar. İstanbul: Alfa Yayınlar1, 2020. 368 sayfa. ISBN: 9786254491153

Ortaçağ Avrupa'sında “Tanrı'nın Kamçısı” (Flagellum Dei) olarak hatırlanan Attila ve Batı Hunları hakkında günümüze ulaşmış kaynakların hepsi Romalı tarihçilerin yazdıklarıdır. Batı Hunları geriye ne yazılı bir kaynak ne de herhangi bir arkeolojik buluntu birakmışlardır. Romalı tarihçiler arasında Attila'yı birinci elden görerek Hunların mekânlarını, merasimlerini, örf ve adetlerini kaydetmiş olan tek kaynak ise II. Theodosios (hük. 401-450) ve Markianos (hük. 392-457) dönemlerinde yaşamış beşinci yüzyıl yazarı Priskos'tur. Priskos'un eseri günümüze sadece onuncu yüzyılda derlenmiş fragmanlar halinde ve diğer Romalı yazarların eserlerinde kullanıldığı ölçüde ulaşmıştır. Turhan Kaçar'in titiz tercümesi ile ilk defa toplu olarak Türkçe'ye çevrilen bu fragmanlar ve alıntılar, Priskos'u tarihsel çerçevede değerlendiren bir giriş yazısı, kapsamlı notlar ve orijinal Yunanca ve Latince metinler ile birlikte Fragmenta et Excerpta: Attila ve Bizans Tarihi olarak okuyucuya sunuluyor. On dokuzuncu yüzyıldan itibaren Osmanlı ve cumhuriyet tarihyazımında dikkate değer yer tutan Attila ve Hunlar hakkında önemli bir boşluğu dolduran eser, aynı zamanda gerekli bir düzeltici görevi görüyor.

Cumhuriyet dönemi tarihyazımında kapsamlı olarak kullanılmış olan Attila figürü ve Hunlara dair tarihsel kurgu, Türkiye'deki ortaçağ çalışmalarının gelişimi hakkında da önemli ipuçları barındırıyor. Cumhuriyet Türkiye'sinin yetiştirdiği ilk kuşak ortaçağ tarihçileri olan Ibrahim Kafesoğlu, Tayyip Gökbilgin, Şerif Baştav ve Hüseyin Namık Orkun'un ortak noktaları hepsinin Dil ve Tarih-Coğrafya Fakültesi'nde Hungaroloji Bölümü'nde okuyup Macaristan'da doktora yapmış ya da daha kısa eğitim görmüş olmalarıyd1. ${ }^{1}$ Magyarlar on üçüncü yüzyıldan itibaren Batı Hun tarihini kendi tarihleri olarak benimsemiş ve Attila figürünü diğer bazı ortaçağ toplumlarından farklı olarak kahraman ve soylu bir karakter olarak kurgulamışlardı. Rönesans Macar metinlerinde Attila figürü Corvinus hanedanının meşrulaştırılması ve Osmanlılara karşı ortak bir kan bağı sağlaması için kullanılmıştı.
On dokuzuncu yüzylla gelindiğinde ise Macar ideologlar pan-Germencilik ve pan-Slavizm akımlarına karşı içinde Türki ögeler barındıran ve Hunlara referans veren milli bir Macar kimliği geliştirmişlerdi. ${ }^{2}$ Türkiye tarihyazımındaki Attila figürü ve Hun tarihi anlatısı ise on dokuzuncu ve yirminci yüzyll Macar ideolojik süzgecinden geçerek popüler anlatı düzeyinde tedavüle girdi. ${ }^{3}$

Kaçar'in Attila ve Hunlar ile ilgili güncel Batı literatürünü tarayan çalışması Priskos'un tanıklığı üzerinden konu hakkındaki Roma tarihini yeniden değerlendirmek için gerekli altyapıyı hazırlıyor. Telif eserleri ve tercümeleri ile Türkiye'de geç antikçağ ve erken ortaçağ tarih çalışmalarına büyük katkıda bulunan Kaçar, Priskos'u İspanya kökenli II. Theodosios'a muhalefet eden Trakyalı bir bürokrat olarak okuyor. Bu sayede Priskos'un çizdiği Attila ve Hunlar portresini, dönemin Roma siyasi dünyasına yerleştiriyor. Özellikle Priskos'un Attila'nın sarayının bulunduğu köyde karşılaştığı Yunan'in Roma düzeni hakkındaki eleştirilerini bu bağlamda değerlendiriyor. Yine, II. Theodosios'un elçilik görevi ile Attila'ya gönderdiği Maksiminos'a Roma İmparatoru'nun Attila'ya yapilması planlanan suikast hakkında bilgi vermemiş olmasını ve Priskos'un birinci elden bildiği konuyu sunuş biçimini benzer bir kaiserkritik olarak sunuyor. Türkiye tarihyazıcılığında Attila'nın bir dünya hükümdarı olarak resmedilmesi için kullanılan farazi Sasani seferini de gene Roma siyasi dinamikleri bağlamında inceliyor. Düzenlenmesi düşünülen Sasani seferi ile ilgili bilginin Batı Romalı elçiler vasıtasıyla aktarıldığına dikkat çeken tercüman Batı Romalı siyasetçilerin Attila'yı Doğu'ya yönlendirerek kendilerine yönelik tehdidi bertaraf etmek istediğini not ediyor. Kaçar, Konstantinopolis'teki saray hadımlarının etkin gücünden, Batı ve Doğu Roma arasındaki siyasi çekişmelere, Sasaniler'den Kuzey Afrika'ya Roma dünyasının kültürel ve sosyal dinamiklerine geniş bir yelpazeden yaklaşıyor. Sonuç olarak Priskos'un ve dolayısıyla Attila'nın şimdiye kadar Türkiye tarihyazıcılığında karşılaşılan basitleştirilmiş tasvirinden farklı bir resim çiziyor.

Türkçe çeviriyi zenginleştiren notların diğer bir özelliği eserin etnografik özelliklerinin altını çizerek Priskos'un Herodot referanslarını detaylandırması. Priskos'un orijinal Yunancasına sadık kalan tercümede Attila ve Hunlar yer yer İskitli olarak adlandırılıyor. Hero- dot'tan itibaren Karadeniz'in kuzeyinde yaşayan ve göçebe gelenekten gelen halkları İskitli olarak isimlendirmek klasik Yunan tarihyazıcılığı geleneği ile devamlılık gösteren Roma tarihyazıcılığında yaygın bir yöntemdi. ${ }^{4}$ Priskos'un hem Hunlara İskitli demesi hem de Attila'nın sarayındaki ziyafeti, Hunların kıyafetlerini, maddi kültürlerini, ahşap işçiliği ile yapılmış evlerini, kadınların Hun toplumundaki yerini ve evlilik adetlerini, Attila'nin cenaze merasimini anlatması klasik Yunan ve Roma tarihyazıcılığındaki etnografik ilginin bir sonucu. Eserin bu yönünün altını çizen notlar Priskos'un doğru çerçevede okunmasına yardımcı oluyor. Özellikle iki pasaj bu bağlamda öne çıkıyor. Attila'nın Hun kadınları Romalı elçilere cinsel ilişkiye girmeleri için takdim etmesini, Kaçar Herodot'taki İskitli erkeklerle Amazon kadinların bir araya gelmesini anlatan ünlü pasajlar çerçevesinde değerlendiriyor. Barbar ve Romalı arasındaki gelenek farklarına dikkat çeken pasaj, Hunlar kadar Priskos'un ait olduğu toplum hakkında da bilgi veriyor. Tercüman, Priskos'un bu detayı hatırlaması ve anlatıya dâhil etmesini klasik tarihyazıcılığı geleneği içinde anlamlandırıyor. Diğer pasaj ise ortaçağ Magyar toplumunda efsaneye dönüşmüş olan Attila'ya ait olan Ares'in kılıcı hikâyesi. $\mathrm{Bu}$ anlatı Priskos'tan bir yüzyıl sonra yaşamış, Priskos'un eserinden pasajlar aktarmış ve eserini Latince yazmış ünlü tarihçi lordanes’in eserinde bulunuyor. lordanes'in Latince tarihinin ortaçağdaki geniş kullanımı, efsanenin Magyar kralları tarafından sahiplenilmesine ve Attila'nın kılıcı olduğuna inanılan bir kılıcın bu krallar tarafından kullanılması ile daha da dallanıp budaklanmasına sebep oluyor. Rönesans'ta da hükümdar kültü ile ilişkilendirilmiş Magyar krallarinın bu kılıcı halen Viyana'da Kunsthistorisches Müzesinde saklanıyor. Her ne kadar kılıç ile ilgili efsane geç antikçağ yazarlarının eserlerinin daha sonraki yüzyıllarda farklı şekillerde kullanımlarına işaret ediyor olsa da, Priskos'u kendi tarihsel çerçevesinde okumak için yarar sağlamayacağı açık. Mevcut eser Priskos anlatısını kendi zamanının siyaseti ve entelektüel geleneği içinde değerlendirmek için ihtimam gösteriyor. Türkçe tercüme ve notlarda, bu geç ortaçağ efsanesine vurgu yapılmıyor. Priskos'un anlatisinın esasen Herodot'taki İskit kralları için kutsal olan kılıç motifi ile ilgili olduğunun altı çiziliyor. Bu sayede efsane teleolojik bir şekilde değil Priskos'un geldiği Yunan ve Roma geleneği içinden okunuyor. 
Tercüman dikkat çekmek istediği yahut Priskos'un diğer Romalı yazarlardan ayrıldığı hususlarda Türkçe tercümenin yanında parantez içinde orijinal terimleri ekliyor. Mesela irk anlaminda da tercüme edilebilen ama modern dillerde tam karşlığı bulunmayan ve Herodot'un anlatıyı düzenleyici bir kavram olarak yaygın olarak kullandığı genos kelimesi üç değişik pasajda üç değişik şekilde tercüme ediliyor. Her tercümenin yanında orijinal terim de sunuluyor. Genos kelimesi ilk olarak millet (s. 65), daha sonra soy (s. 77) ve irk (s. 89) olarak tercüme ediliyor. Bu sayede tercüme metinde kelimenin nüansları vurgulanıyor. Parantez içinde sunulan başka bir kelime ise Helen terimi. Hristiyan dininin Roma devleti için yeni din olduğu ve eski dine inananların halen bulunduğu beşinci yüzyllda yazan Priskos'un kullandığı Helen kelimesi pagan olarak tercüme ediliyor ve Yunancası parantez içinde veriliyor. Latince'de kırsal bölge anlamina gelen pagus'tan türemiş olan paganus kelimesi, Batı Roma'da Hristiyanların eski dine inanlar için kullandığı ve çok tanrıcı dinin Hristiyanlık kabul edildikten sonra bile şehirler dişındaki bölgelerde halen devam ettiğini hatırlatan bir kelimeydi. Latince yerine Yunancanın daha yaygın olduğu Doğu'da ise eski dine inananlar Helen dinine inanlar olarak tanımlanıyordu. Orta ve geç Bizans dönemlerinde de Doğu'da Helen kelimesi dil dışında aynı zamanda din anlamında kullanılmaya devam edilmişti. ${ }^{5}$ Böylece parantez içinde belirtilen bu kelime Hristiyanlığın ve eski dinin Doğu ve Batı'da farklı tezahürlerine işaret ediyor. Parantez kullanılan bir diğer örnek ise Yunancada hem kral hem de imparator anlamina gelen basileus kelimesi. Priskos bu kelimeyi Attila için kullanıyor. Priskos'un bu kullanımı tercümanın da parantezle işaret ettiği üzere beşinci yüzyil bağlamında son derece şaşırtıcı. Geç Antikçağ'da evrensel imparatorluk ideolojisine sahip olan Romallar, Sasaniler dışındaki hasımları ve barbar kavimler için bu kelimeyi nadiren kullanıyorlardı. Attila'yı basileus olarak tanımlayan Priskos, Hun lideri diğer barbarlardan farklı olarak değerlendirdiğini ima ediyordu.

Hem Türkiye tarihyazıcılı̆̆ında ve daha genel olarak küresel tarih anlatılarında Attila ve Hunlar, kavimler göçünün ilk dalgası olarak Doğu ve Batıyı bağlayan Türki bir kavim olarak sunulmaktadır. Attila ve Batı Hunları için Romalı tarihçilerin eserleri dışında bir kaynak olmadığı ve Priskos'un da Romalı tarihçiler arasında Attila'yı şahsen görmüş tek yazar oldu- ğu göz önüne alındığında, konu hakkında yakın okuma yapılmasının gerekli olduğu ortadadır. Eserde bu tartışmalı nokta hakkında nihai bir karar verilmeden eldeki veriler notlarda sunuluyor. Öncellikle Priskos'un, mevcut metinlerin hiçbirinde Hunların kökeni hakkında herhangi bir bilgi vermediğinin altı çiziliyor. Öte taraftan Priskos'tan evvel ve dördüncü yüzyılda yazmış olan Ammianus Marcellinus'un Hunların Maeotis (Azak) Denizỉnin ötesinde yaşadığını kaydettiği ekleniyor. Hunların Asya kökenli olduklarını öne süren bibliyografyayı yan tutmadan sunan eserde, Hunların Türki kökenleri olabileceği hakkındaki etimolojik savlar göz ardı edilmiyor. Türki diller (s. 137) ve Kırgızca (s. 334) ile kökteş olabilecek Hunca kelimeler dipnotlarda belirtiliyor. Son tahlilde Priskos'un eserinden çıkarılabilecek Hunların Asya kökenli olduklarına dair kanıtlar oldukça zayıf gözüküyor.

Eserde Priskos'un onuncu yüzyılda derlenmiş fragmanları, diğer Romalı tarihçilerin eserlerinde geçen Priskos alıntıları ve orta Bizans döneminde bir çeşit ansiklopedi olarak tasarlanmış Suda'da geçen Priskos'tan bölümler olayların tahmini kronolojik düzeni içinde bir araya getiriliyor. Priskos'tan alıntı yapan Romalı yazarlar arasında sadece altıncı yüzyıl tarihçisi Prokopios yahut sekizinci ve dokuzuncu yüzyll kroniği Theophanes gibi Yunanca yazanlar değil aynı zamanda Latince yazmış olan altıncı yüzyıl tarihçisi lordanes de bulunuyor. Alıntı ve fragmanlar için F. Bornmann'in ve P. Carolla'nın yayınladığı tenkitli neşirler ve önerdikleri kronolojik sıra, diğer Romalı tarihçiler için yapılmış tenkitli neşirler ve R. C. Blockley'nin Ingilizce tercümesi kullanılıyor. Her fragmanın başlığında alıntının değişik tenkitli neşirlerinin ve İngilizce tercümenin sayfa numaraları veriliyor. Türkçe tercüme, paralel orijinal Yunanca ve Latince metinler ile birlikte sunuluyor. Sayfa düzeni son derece başarılı bir şekilde tertip edildiği için orijinal dilde de metin kolayca takip ediliyor. Eser ilk defa Türkçe'ye çevriliyor olmasına rağmen neredeyse hiç tercüme hatası bulunmuyor (s. 118'de "kraliyet ikametgâhının dış surlarına" yerine "dış surlara" ve s. 161'de "Zeno'nun önünde sonunda" yerine "Zeno'nun eninde sonunda" olması gerekir).

Yirminci yüzyılda Türkiye ortaçağ tarihçiliğinin Batı Avrupa tarihçiliğine kenetlenme noktasını teşkil eden Hunlar ve Attila hakkındaki anlatılar şimdiye kadar Türkiye'de yapılan çalışmalarda Roma dünyasının dinamiklerinden ari olarak incelenmiştir. Oysa Priskos, Prokopios, lordanes ve diğer Romalı yazarların Hunlar hakkında aktardıkları geç antikçağ Roma dünyasının siyasi çekişmeleri, sosyal ve hukuk düzeni, dini ve askeri dönüşümlerinin içinden filizlenen ve klasik Yunan ve Roma entelektüel geleneği çerçevesinde anlaşılabilecek bilgilerdi. Hunları Roma tarihsel çerçevesinden sunan Attila ve Bizans Tarihi eseri sayesinde Priskos ilk defa olarak Türkçe'ye geniş kapsamlı olarak kazandırılıyor. Yirminci yüzyıl cumhuriyet tarihyazıcılı̆̆ında basite indirgenmiş şekilde kullanılıp tarihsel bağlamı dışında alıntılanmış Priskos'u hak ettiği şekilde doğru ve akıcı bir tercüme, ayrıntılı notlar, zengin bir bibliyografya, detaylı bir dizin ve son derece yararlı bir giriş yazısıyla tanıtan Attila ve Bizans Tarihi kuşkusuz Türkiye ortaçă̆ tarihçiliğine büyük katkı sağlayacaktır.

\section{Aslıhan Akışık-Karakullukçu}

Tübitak-2219 Bursiyeri

Wolfson College, Oxford

aslihanakisik@gmail.com

1 Macar, Hun ve Türk tarihi arasındaki bağlantıları çalışmış olan tarihçiler Attila hakkında da eserler verdiler. Ibrahim Kafesoğlu, Türk Milli Kültürü (İstanbul: Türk Kültürünü Araştırma Enstitüsü, 1977); Şerif Baştav, Büyük Hun Kağanı Attila (Ankara: Kültür Bakanlığı Yayınları, 1998); Hüseyin Namık Orkun, Attila ve Oğulları (İstanbul: Remzi Kitaphanesi, 1933).

2 On dokuzuncu ve yirminci yüzyıllarda Batı ve Doğu arasında tartışmalı bir konumda bulunan Macar toplumu, görsel sanatlar alanında da Macarları oryantal bir "öteki” olarak sunuyordu. Bkz. Terri Switzer, "Hungarian Self-Representation in an International Context: The Magyar Exhibited at International Expositions and World's Fairs," Art, Culture, and National Identity in fin-de-siècle Europe (Cambridge: Cambridge University Press, 2003), 160-186.

3 Macar Bizans tarihçisi Gyula Moravcsik ve Türkolog Gyula Németh’in öğrencisi olmuş Türkiye kökenli ortaçağ tarihçileri, Attila ve Hunlar hakkındaki Macar literatürünü de Türkçe’ye çevirdiler. Gyula Moravcsik, Türk Tarihinin Bizans Kaynakları, çev. Hüseyin Namık Orkun (Ankara: Sümer Basımevi, 1938); Gyula Németh, Attila ve Hunlarl, çev. Şerif Baştav (İstanbul: Ankara Üniversitesi, 1962). 4 Kapsamlı olarak çalışılmış konuya yeni bir bakış açısı getiren son eser için bkz. Rustam Shukurov, The Byzantine Turks, 1204-1461 (Leiden: Brill, 2016). 5 On beşinci yüzyılda yaşamış ve Neoplatonist filozof Georgios Gemistos Pletho'nun öğrencisi olan Laonikos Khalkokondyles, bu geç tarihte Helen dinine inanların halen Bohemya'da bulunduğunu yazar. Helen dinini Apollon ve Artemis kültü olarak tanımlayan tarihçinin eseri ile Pletho'nun kullanmış olduğu bir Herodot elyazması (Plut. Gr. 70.06) ve bu elyazmasındaki Apollon ve Artemis sembolleri arasındaki geçişler geç Bizans döneminde de eski dinin etkisinin devam ettiğini gösteriyor. Bkz. Asl1han Akış1k, Self and Other in the Renaissance: Laonikos Chalkokondyles and Late Byzantine Intellectuals (doktora tezi, Harvard University, 2013). 